\title{
Spontaneous retinal pigment epithelial rip
}

Kosyilya Arumugam, Ayesha Mohd Zain, Mushawiahti Mustapha

Department of Ophthalmology, Universiti Kebangsaan Malaysia, Kuala Lumpur, Malaysia

\section{Abstract}

This is a case report of a spontaneous retinal pigment epithelial (RPE) rip in a 64-year-old woman who presented with progressive, painless, blurring of vision in her right eye for 2 weeks. Her vision was $6 / 60$ in the right eye and $6 / 6$ in the left eye. On fundoscopy, there was a large depigmented area over the right posterior pole. A large area of RPE rip involving the fovea was revealed via optical coherence tomography and angiogram. Spontaneous RPE rip is a rare manifestation. However, when the fovea is involved the visual prognosis is poor. This article aims to highlight the vital role of multimodal imaging in aiding the diagnosis of RPE rips or tears.

Keywords: retinal pigment epithelium, retinal pigment epithelium rip, retinal pigment epithelium tear

Correspondence: Ayesha Mohd Zain, MBBS (UIA), Department of Ophthalmology, UKMMC, Jalan Yaacob Latif, Bandar Tun Razak, Cheras, 56000, Kuala Lumpur, Malaysia.

E-mail: ayesha.mohdzain@gmail.com 


\section{Pemisahan epitel pigmen retina secara spontan}

\section{Abstrak}

Ini adalah laporan kes pemisahan epitel pigmen retina secara spontan (RPE) pada wanita berusia 64 tahun yang mengalami pengaburan penglihatan mata kanan selama 2 minggu. Penglihatannya 6/60 di mata kanan dan 6/6 di mata kiri. Dalam funduskopi terdapat kawasan pemisahan RPE yang besar. Sebilangan besar koyakan RPE yang melibatkan fovea didedahkan melalui tomografi koheren optik dan angiogram.Koyakan RPE spontan adalah manifestasi yang jarang berlaku. Walau bagaimanapun, apabila fovea terlibat, prognosis visual adalah kurang baik. Artikel ini bertujuan untuk menonjolkan peranan penting pengimejan multimodal dalam membantu diagnosis koyakan RPE.

Kata kunci: epitel pigmen retina, koyakan epitelium pigmen retina, rip epitel pigmen retina

\section{Introduction}

Spontaneous large retinal pigment epithelial (RPE) rip is an uncommon sightthreatening complication usually associated with wet age-related macular degeneration. ${ }^{1}$ Recently, due to the vast use of anti-vascular endothelial growth factor (anti-VEGF), there has been a rise in the occurrence of RPE rips. ${ }^{2}$ RPE tears or rips are graded based on the most significant linear diameter of the tear, measured by fluorescein angiography. ${ }^{3}$ This case highlights a spontaneous large RPE rip diagnosed with multimodal imaging.

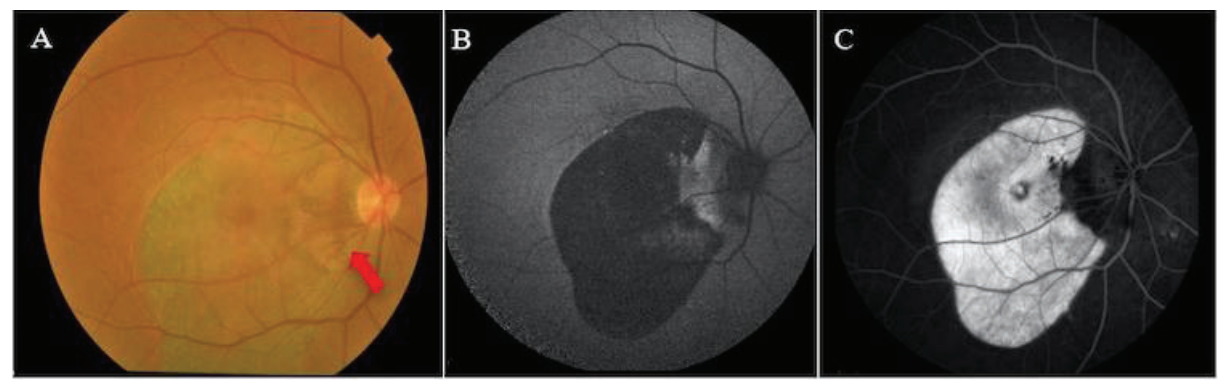

Fig. 1. (A) Right eye fundus showing large depigmented area at the posterior pole extending to the inferior retina and pigmented area nasally (arrow). (B) Autofluorescence of the right eye showing hypofluorescence over bare area devoid of RPE. (C) FFA of the right eye with a large area of window defect. 


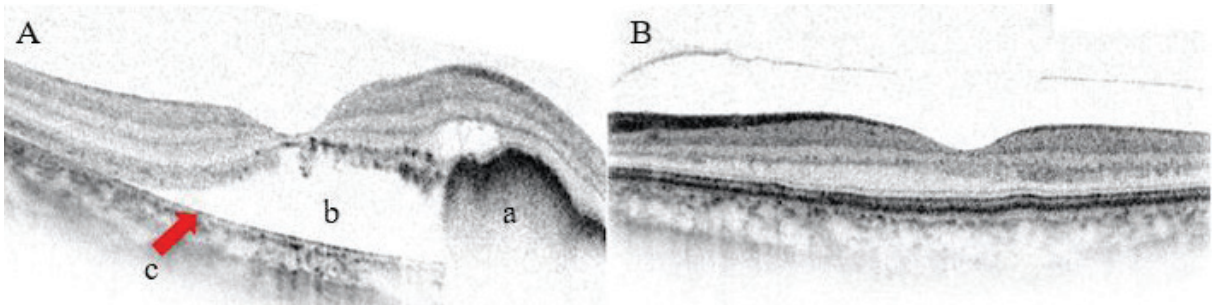

Fig. 2. (A) Right eye OCT showing disruption of the RPE layer, hyper-reflectivity on the nasal side due to the rolled RPE. (a) Presence of empty subretinal space. (b) RPE is missing with a visible Bruch's membrane ( $c$ with red arrow). (B) Left eye OCT showing normal contour.

\section{Case report}

A64-year-old woman with underlying hypertension presented with painless blurring of vision and metamorphopsia of the right eye for 2 weeks. She denied history of ocular trauma or taking medication containing steroids. Her best-corrected visual acuity (BCVA) was $6 / 60$ in the right eye and 6/6 in the left eye. Her anterior segment examination was otherwise unremarkable.

On fundus biomicroscopy, there was a large depigmented area over the right posterior pole extending to the inferior retina (Fig. 1A). The area was crescent-shaped, with a well-demarcated margin. There was an adjacent hyperpigmented area nasally. Clinically, the depigmented area resembled an area of absent RPE with bare choroid, whereas the adjacent hyperpigmented lesion represented redundant retracted RPE. However, there was no retinal haemorrhage, drusen, orange nodule, pigment epithelial detachment, or other chorioretinal lesions. The left eye revealed normal findings.

On autofluorescence, there was hypoautofluorescence in the area where RPE was void and hyperautofluorescence coinciding with the area of retracted RPE (Fig. 1B). The fundus fluorescein angiogram (FFA) revealed the reverse, with a well-demarcated window defect of hyperfluorescence corresponding to the RPE rip, surrounded by a rim of hypofluorescence nasally caused by retracted RPE (Fig. 1C).

Optical coherence tomography (OCT) revealed a large area devoid of RPE (Fig. 2A). Nasal to the lesion, there was an area of rolled RPE with an irregular contour that was responsible for the dense hyper-reflectivity. This is likely due to the duplication of RPE in that area. The hyper-reflectivity gives rise to an intense posterior shadowing, completely masking the choroid beneath it. 


\section{Discussion}

Vascularized retinal pigment epithelial detachment (PED) in patients with exudative macular degeneration is the most usual cause for RPE tear. ${ }^{2}$ Other reasons that account for this rare manifestation are RPE thinning, choroidal swelling, vitreoretinal traction, blunt trauma, and iatrogenic causes such as laser photocoagulation and photodynamic therapy. ${ }^{2}$

Our patient presented with a spontaneous rip. There was absence of drusen and chorioretinal lesions. Fryczkowsi et al. described a patient with high myopia (refractive error 10.0 D) complicated with RPE tear. Physical forces secondary to ocular movement are passing through the thin sclera and Bruch's membrane to the RPE, predisposing myopes to have RPE rip at the margin of posterior staphyloma. ${ }^{4}$ This was unlikely the case for our patient, as there was no evidence of posterior staphyloma clinically or on OCT. There was also an absence of subretinal haemorrhage.

The most likely cause of RPE rip in this patient is secondary to PED due to the accumulation of hydrostatic pressure within the PED and wearing out of the intercellular connection between RPE cells. ${ }^{5}$ Besides that, the tangential traction on the RPE itself accounts for rips or tears. ${ }^{1}$ Rips occur commonly at the margin of PED, which is the area of significant strain. ${ }^{6}$ There is a retraction of the edge of RPE, exposing the underlying Bruch's membrane and choroidal vessels. ${ }^{3}$

On OCT, the trademark of an RPE rip is the discontinuity in the RPE layer. ${ }^{2}$ Rips tend to occur at the base of PED close to the junction between the attached and detached RPE. ${ }^{2}$ In this patient, the irregular contour of rolled RPE gives rise to increase reflectivity with strong back-shadowing completely masking the choroid. Studies by Doguizi and Ozdex ${ }^{6}$ measured $>580$ um height of PED and $<4.5$ months duration of PED as an important risk factor for RPE rip occurrence after anti-VEGF therapy.

Autofluorescence aids better in detecting small tears compared to fundoscopy. ${ }^{2}$ FFA provides a distinctive appearance of RPE rips where there is an area of hyperfluorescent window defect, which lies parallel to an area of blocked hypofluorescence. ${ }^{1}$ The hyperfluorescence indicates the bare choroid, while the hypofluorescence indicates an area of retracted redundant RPE. ${ }^{1}$

RPE rips may cause a sudden and drastic loss in vision. ${ }^{1}$ The most crucial prognostic factors for recovery are involvement of the fovea and size of RPE rip. ${ }^{3}$ This case study reflects a poor visual prognosis, as the rip involved the fovea. Although photoreceptors can survive up to 325 days post-RPE rip, the surgical outcome for macular translocation, autologous pigment epithelium, and choroidal transplantation does not provide promising benefits. ${ }^{7}$

Spontaneous RPE rips are rare occurrences. Multimodal imaging plays an essential role in the diagnosis of this disease, even though there is no specific treatment for RPE tears. It helps to find the underlying cause of the disease. 


\section{References}

1. Tsujikawa A, Hirami Y, Nakanishi H, et al. Retinal pigment epithelial tear in polypoidal choroidal vasculopathy. Retina. 2007;27(7):832-838. doi: 10.1097/IAE.0b013e318150d864.

2. Gupta A, Chhabra M, Mehta P, Ghosh B. Tears of The Retinal Pigment Epithelium-A Review. The Official Scientific Journal of Delhi Ophthalmological Society. 2017;27(4):243-249. doi: 10.7869/ djo.258.

3. Ersoz MG, Karacorlu M, Arf S, Muslubas IS, Hocaoglu M. Retinal pigment epithelium tears: classification, pathogenesis, predictors, and management. Surv Ophthalmol. 2017;62(4):493-505. doi: 10.1016/j.survophthal.2017.03.004.

4. Fryczkowski P, Jedruch A, Kmera-Muszyńska M. Spontaneous RPE tear in high myopia. Klinikaoczna. 2006;108(7-9):327-331. Available from: https://europepmc.org/article/med/17290835

5. Lim Z, Wong D. Retinal pigment epithelial rip associated with idiopathic central serous chorioretinopathy. Eye. 2008;22(3):471. doi: 10.1038/sj.eye.6703020.

6. Doguizi S, Ozdek S. Pigment epithelial tears associated with anti-VEGF therapy: incidence, long-term visual outcome, and relationship with pigment epithelial detachment in age-related macular degeneration. Retina. 2014;34(6):1156-62. doi: 10.1097/IAE.0000000000000056

7. Sinawat S, Bhoomibunchoo C, Yospaiboon Y, Sinawat S. Spontaneous bilateral retinal pigment epithelium rips with good visual acuity. J Med Assoc Thai. 2014;97(Suppl 10): S115-119. 